\title{
Online Impulse Buying Behavior of Consumer Triggered by Digital Marketing
}

\author{
C.Kathiravan, P.Mahalakshmi, V.Palanisamy
}

\begin{abstract}
Online marketing is bitten by bit getting to be prominent in creating nations like India. The online advertising has developed as another goal which pulls in a great many customers consistently. "Impulse buy" or "impulse buying depict any buy which a consumer makes, however, has not arranged ahead of time (Baumeister, 2002; Stern, 1962). The components that influence the consumer online buying have been uncovered through quantitative research by breaking down information gathered through an internet-based poll overview. This comprised of 90 consumers who were buying online. This examination additionally talks about the administrative issues, recommendations and suggestions for the future analysts. The understanding of buying behaviour of online customers as far as their impulsive conduct would be useful for the advertisers and academicians. The main aim of this paper is to take a gander at the components which striving for online shopping and to build up a comprehension of the variables affecting the online shopping by the consumers.
\end{abstract}

Keywords: Impulsive buying, consumer behaviour, online marketing.

\section{I.INTRODUCTION}

An impulse buy or impulse buying is an impromptu choice to purchase an item or administration, made just before a buy. It is an unrestricted, quick buy without pre-shopping aims either to purchase a particular item classification or to satisfy a particular buying task (Beatty and Ferrell, 1998). As a rule, an assortment of limited-time data can be found in networks. These data at that point go about as boosts to trigger impulse buying conduct whenever and places.

In this way, it is of incredible noteworthiness to uncover the impact of online impulse buying to rehearses. It causes organizations to all the more likely invigorate consumers' longing to purchase through Web, versatile terminals and $\mathrm{O} 2 \mathrm{O}$. Likewise, it urges organizations to create compelling advertising procedures to build their impulse buying conduct (Lee et al., 1989) Study has demonstrated that impulse buying is a region which might happen to more enthusiasm to retailers just as advertisers and producer's

Revised Manuscript Received on July 22, 2019.

DR.C.KATRIRAVAN, Associate Professor, Department of Business Administration, AnnamalaiUniversity, E-Mail: kathirc@gmail.com

P.MAHALAKSHMI*, Corresponding Author: Doctoral Research Scholar, Department of Business Administration, Annamalai University E-Mail: neha86maha@gmail.com

V.PALANISAMY, Assistant Professor, Department of Business Administration, St.Joseph University, Nagaland.

E-Mail: palanisamyv96@gmail.com worldwide as it is a reason that can build deals volumes and develop their primary concern On the off chance that the online retailer comprehended components that empower impulse buys online, even a one per cent increase in deals from impulse buying would prompt an extra $\$ 55$ million in income, bringing about a huge effect to both the online retailer and the business. It is subsequently association for the retailers to realize the online impulse buy conduct and the various elements that could impact the purchasers, including in it. The general motivation behind this examination paper is to assemble further comprehension of the different viewpoints which are fundamentally identified with the impulse buying of the online customers.

\section{REVIEW OF LITERATURE:}

Ekeng and et al. (2012), statistic qualities impact impulse buying. Impulse buying varies necessarily among male and female customers, where the wonder is increasingly standard among female customers because of their similarity and unconstrained appreciation for extravagant items. So also the period of customers and impulse buying conduct are conversely related because teenagers have no obligation of raising families and they don't make a fuss over how they burn through cash regardless of whether it is spontaneous when contrasted with more established individuals. Moreover, an expansion in the pay of consumers makes them extravagant in spending and may impact on purchasing items spontaneously. Increasingly taught, consumers are probably going to shop impulsively as they are impacted by their position and situation in the public eye. Piron (1991) portrayed Impulse buying as an impromptu buy, aftereffect of an introduction to improvement, and chose the spot. Amid impulse buying, there is a substantial and unexpected want to purchase an item absent much consideration, which one didn't mean to buy before entering the store (Rook and Fisher, 1995). Verhagen and Dolen (2011) found that impulsive buying visibly happens in about $40 \%$ of every single moment online consumption and further suggested the comprehension of consumer buying conduct in online exchanges is urgent for the online retailing experts. Rawlings (1995) found that youthful shows more grounded impulse buying conduct than the old. By exploring the US grown-up populace, Wood (1998) found that age bears no direct association with the impulse buying conduct. In any case, he understood that individuals matured 18 to 39 have a higher inclination of impulse buying conduct, while individuals matured

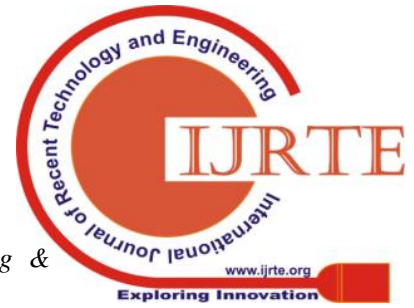


more than 39 have a lower propensity of it. Fygenson (2006) liken online shopping to web-based business and propose the definition that web-based business is where consumers get data and buy items utilizing Web innovation. Kathiravan (2013) find and analyse the cause influence variables in basis supportive decision on the predominant cause. It tends to be expressed that the logical way to deal with buying online is related to specific client conduct and their variety/aim of buying online.

\section{OBJECTIVES}

- To identify the factors which are influencing to the consumer to buy impulsively in online

- To determine the significance of socio-economic factors and consumer opinion of impulsive buying in electronic retailing

- To offer valuable suggestions to online marketing retailers based on the findings of the study.

\section{FACTORS INFLUENCING ONLINE IMPULSIVE BUYING}

In recent years, surveyors of information system argued that in the context of online retail shopping, the environment of the online shop had a significant impact on consumer behaviour. Online impulse purchases as a fragment have huge growth potential with rising in e-buying, according to DAWSON and KIM (2009).

\section{A.SOCIO-ECONOMIC FACTORS:}

Impulse buying behaviour of consumers in the age group 18-39 shows a similarity pattern, and it decreases as age increases (WOOD, 1998; GHANI et al., 2011). Gender and social attributes have an impact on an impulse purchase, according to DITTMAR et al. (1996). Female customers show interest in products that show symbolism and are self-expressing and are easily mixing with their emotional self and appearance. Lin and Lin (2005) discovered that the disposable income of young people bears a positive relationship with impulse buying behaviour. As their disposable income increases, they are more likely to buy products impulsively.

\section{Research Methodology}

The research procedure is a practical examination to give answers for logical and social issues through the investigation of research strategies. It is an orderly strategy to touch base at the outcome by method for preparing and breaking down the issue with the utilization of different strategies/systems. The examination strategies are arranged, logical, and esteem impartial. These techniques incorporate hypothetical methodology, measurable methodologies, trial ponders, numerical plans, and so on.

\section{Research Design}

Research design is a structure or sketch for intelligently completing an exploration without assumption or preference to concoct arrangement of the issue concerned. It clarifies the usual way of doing things necessary for gathering the information or data required for taking care of the examination issues.

Research Hypothesis :

$\mathrm{H}_{0}$ (Null Hypothesis): There is no relationship between socio-economic factors of respondents and consumer opinion about online shopping of impulsive buying behaviour

$\mathrm{H}_{1}$ (Alternative Hypothesis): There is a significant relationship regarding socio-economic factors of respondents and consumer opinion about online shopping of impulsive buying behaviour

\begin{tabular}{|c|c|c|c|}
\hline Variables & Options & $\begin{array}{c}\text { No. of } \\
\text { respondents }\end{array}$ & Percentage \\
\hline \multirow{3}{*}{ Gender } & Male & 19 & 21.1 \\
\hline & Female & 71 & 78.9 \\
\hline & Total & 90 & 100.0 \\
\hline \multirow{5}{*}{ Age group } & Below 25 years & 48 & 53.3 \\
\hline & 26 - 35 years & 35 & 38.9 \\
\hline & $36-45$ years & 7 & 7.8 \\
\hline & Above 45 years & - & - \\
\hline & Total & 90 & 100 \\
\hline \multirow{5}{*}{$\begin{array}{c}\text { Education } \\
\text { qualifications }\end{array}$} & Up to school level & - & - \\
\hline & Diploma & - & - \\
\hline & UG & 61 & 67.8 \\
\hline & PG & 29 & 32.2 \\
\hline & Total & 90 & 100 \\
\hline \multirow{5}{*}{ Occupation } & Student & 39 & 43.3 \\
\hline & Private employee & 33 & 36.7 \\
\hline & $\begin{array}{l}\text { Government } \\
\text { employee }\end{array}$ & 13 & 14.4 \\
\hline & Business & 5 & 5.6 \\
\hline & Total & 90 & 100.0 \\
\hline \multirow{3}{*}{ Marital status } & Single & 57 & 63.3 \\
\hline & Married & 33 & 36.7 \\
\hline & Total & 90 & 100.0 \\
\hline \multirow{5}{*}{ Monthly Income } & Up to Rs. 15,000 & 49 & 54.4 \\
\hline & Rs.15,001-Rs. 20,000 & 16 & 17.8 \\
\hline & Rs.20,001-Rs.25,000 & 10 & 11.1 \\
\hline & Above Rs.25,000 & 15 & 16.7 \\
\hline & Total & 90 & 100.0 \\
\hline \multirow{4}{*}{ Residential area } & Rural & 41 & 45.6 \\
\hline & Semi-urban & 24 & 26.7 \\
\hline & Urban & 25 & 27.8 \\
\hline & Total & 90 & 100.0 \\
\hline \multirow{3}{*}{ Type of family } & Joint & 32 & 35.6 \\
\hline & Nuclear & 58 & 64.4 \\
\hline & Total & 90 & 100.0 \\
\hline \multirow{5}{*}{ Size of family } & Up to 3 members & 28 & 31.1 \\
\hline & 4-6 members & 41 & 45.6 \\
\hline & 7-9 members & 9 & 10.0 \\
\hline & Above 9 members & 12 & 13.3 \\
\hline & Total & 90 & 100.0 \\
\hline
\end{tabular}

Source: Primary data 
Table I shows that the socio-economic profile of the respondents. Out of 90 respondents, 71 respondents are female, 48 respondents are in below 25 years age group, 61 respondents are UG degree holders, 39 respondents are private employees, 57 respondents are single, 49 respondents have income Up to Rs.15,000, 41 respondents are living in rural areas, 58 respondents have nuclear family, and 41 respondents have 4-6 family members.

Table- II: Consumers' Opinion about Online shopping

\begin{tabular}{|c|c|c|c|c|c|c|c|}
\hline S.No & Benefits & SA & A & M & DA & SDA & $\underset{n}{\text { Mea }}$ \\
\hline 1 & $\begin{array}{l}\text { I often buy things } \\
\text { impulsively }\end{array}$ & 32 & $\begin{array}{l}3 \\
1\end{array}$ & $\begin{array}{l}2 \\
3\end{array}$ & 0 & 3 & 3.99 \\
\hline 2 & $\begin{array}{l}\text { I often buy things } \\
\text { exclusive of thinking }\end{array}$ & 24 & $\begin{array}{l}3 \\
1\end{array}$ & $\begin{array}{l}1 \\
6\end{array}$ & 11 & 7 & 3.6 \\
\hline 3 & $\begin{array}{l}\text { Buy now, and feel } \\
\text { later describes me }\end{array}$ & 9 & $\begin{array}{l}2 \\
8\end{array}$ & $\begin{array}{l}3 \\
8 \\
\end{array}$ & 8 & 6 & 3.29 \\
\hline 4 & $\begin{array}{l}\text { I bought more than I } \\
\text { had considered buying }\end{array}$ & 39 & $\begin{array}{l}3 \\
5\end{array}$ & $\begin{array}{l}1 \\
2 \\
\end{array}$ & 3 & 0 & 4.23 \\
\hline 5 & $\begin{array}{l}\text { I felt exciting } \\
\text { shopping when in time } \\
\text { of online sites }\end{array}$ & 4 & $\begin{array}{l}2 \\
8\end{array}$ & $\begin{array}{l}3 \\
8\end{array}$ & 19 & 0 & 3.19 \\
\hline 6 & $\begin{array}{l}\text { I buy a product or } \\
\text { services to lift my } \\
\text { mood that moment }\end{array}$ & 28 & $\begin{array}{l}3 \\
3\end{array}$ & $\begin{array}{l}2 \\
2\end{array}$ & 6 & 0 & 3.93 \\
\hline 7 & $\begin{array}{l}\text { I buy things according } \\
\text { to think at a moment }\end{array}$ & 6 & $\begin{array}{l}4 \\
2\end{array}$ & $\begin{array}{l}2 \\
5\end{array}$ & 9 & 7 & 3.36 \\
\hline 8 & $\begin{array}{l}\text { Spontaneous buying } \\
\text { make me happy to } \\
\text { shop impulsively }\end{array}$ & 21 & $\begin{array}{l}4 \\
0\end{array}$ & $\begin{array}{l}1 \\
5\end{array}$ & 13 & 0 & 3.78 \\
\hline 9 & $\begin{array}{l}\text { I carefully plan most } \\
\text { of my shopping } \\
\text { moment }\end{array}$ & 38 & $\begin{array}{l}3 \\
1\end{array}$ & $\begin{array}{l}1 \\
7\end{array}$ & 3 & 0 & 4.17 \\
\hline 10 & $\begin{array}{l}\text { For me, shopping is an } \\
\text { adventure }\end{array}$ & 10 & $\begin{array}{l}3 \\
9\end{array}$ & $\begin{array}{l}3 \\
1\end{array}$ & 6 & 3 & 3.53 \\
\hline 11. & $\begin{array}{l}\text { I buy product or } \\
\text { services if I can get } \\
\text { free products }\end{array}$ & 22 & $\begin{array}{l}3 \\
2\end{array}$ & $\begin{array}{l}2 \\
0\end{array}$ & 12 & 3 & 3.64 \\
\hline 12. & $\begin{array}{l}\text { Free services can be } \\
\text { the reason for me to } \\
\text { buy on impulse }\end{array}$ & 21 & $\begin{array}{l}2 \\
2\end{array}$ & $\begin{array}{l}3 \\
3\end{array}$ & 10 & 3 & 3.53 \\
\hline 13. & $\begin{array}{l}\text { I buy the product } \\
\text { online with various } \\
\text { offers and discounts }\end{array}$ & 12 & $\begin{array}{l}4 \\
4\end{array}$ & $\begin{array}{l}2 \\
7\end{array}$ & 6 & 0 & 3.69 \\
\hline 14. & $\begin{array}{l}\text { If I see an economical } \\
\text { price, I tend to buy } \\
\text { impulse }\end{array}$ & 12 & $\begin{array}{l}3 \\
1\end{array}$ & $\begin{array}{l}3 \\
9\end{array}$ & 7 & 0 & 3.54 \\
\hline 15. & $\begin{array}{l}\text { I usually make } \\
\text { purchases on impulse. }\end{array}$ & 21 & $\begin{array}{l}2 \\
5\end{array}$ & $\begin{array}{l}3 \\
9\end{array}$ & 4 & 0 & 3.7 \\
\hline
\end{tabular}

Table II explains the consumers' impulsive buying behaviour towards online shopping with the mean score. Fifteen

Statements are framed with the five-point scale for analysing the respondents' opinion. From these statements, 'I carefully plan most of my shopping moment' statement got the highest mean score is 4.17 and'I felt exciting shopping when in time of online sites' statement got the least mean score.
Table- III: Analysis of Gender and Consumers' Opinion

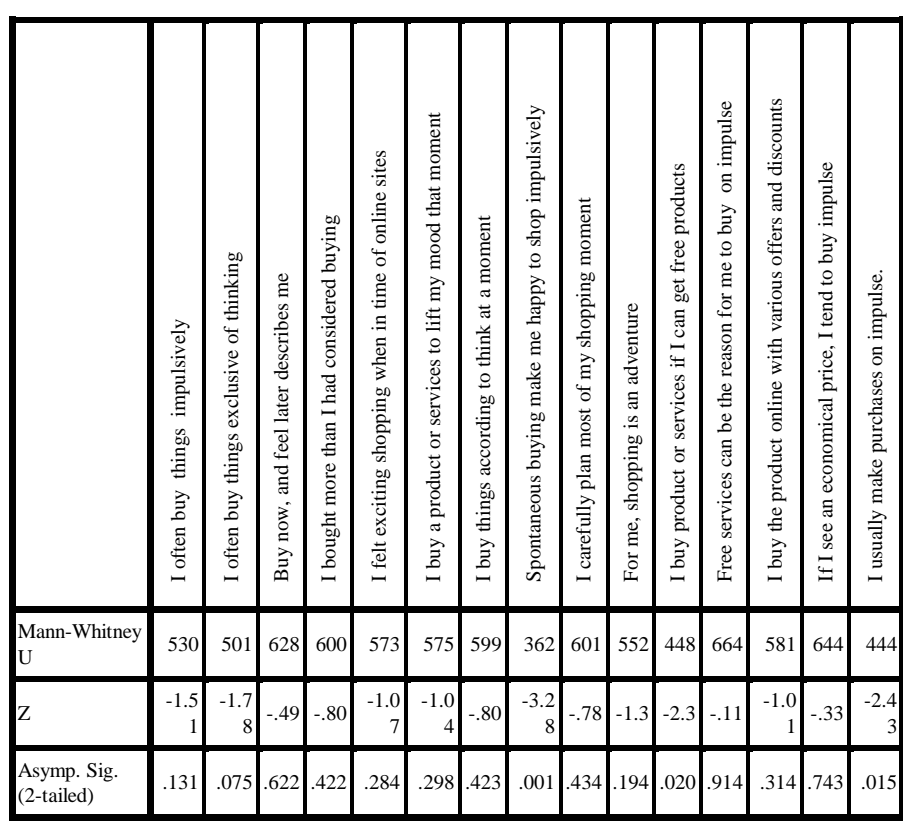

a. Grouping Variable: Gender of the respondents

Table III analyses the relationship between gender and consumers' opinion. There is no Association between gender and consumers' opinion about I often buy things impulsively, I often buy things exclusive of thinking, Buy now, and feel later describes me, I bought more than I had considered buying, I felt exciting shopping when in time of online sites, I buy a product or services to lift my mood that moment, I buy things according to feel at a moment, I carefully plan most of my shopping moment, For me, shopping is an adventure, Free services can be reason for me to buy impulsively, I buy product in online with various offers and discounts, If I see a discounted price, I have a tendency to buy impulse. H1 is Rejected

There is an association between gender and consumers' opinion about Spontaneous buying make me happy to shop impulsively, and I buy product or services if I can get free products, I usually make purchases on impulse. Because the null hypothesis is rejected. 
Table- IV: Analysis of Age group and Consumers' Opinion

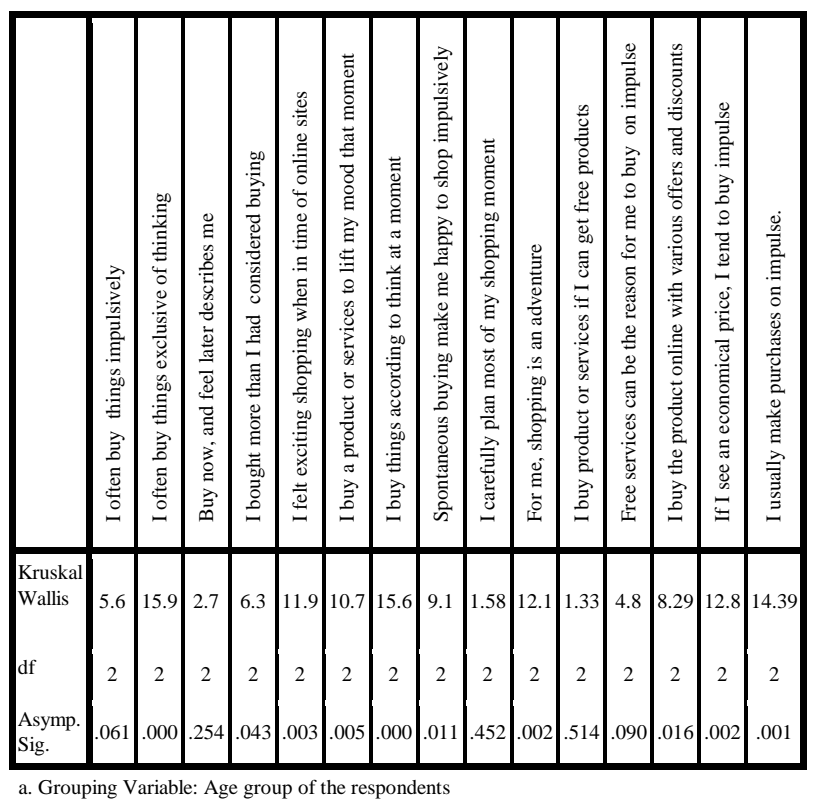

Table IV scrutinizes the relationship between age group and consumers' opinion. There is no association between age group and consumers' opinion about I often buy things impulsively, Buy now, and feel later describes me, and I carefully plan most of my shopping moment, I buy product or services if I can get free products, Free services can be reason for me to buy on impulse because null hypothesis is accepted.

There is Association between age group and consumers' opinion about I often buy things exclusive of thinking, I bought more than I had considered buying, I felt exciting shopping when in time of online sites, I buy a product or services to lift my mood that moment, I buy things according to think at a moment, Spontaneous buying make me happy to shop impulsively, For me, shopping is an adventure, I buy product in online with various offers and discounts, If I see an economical price, I have a tendency to buy impulse, I usually make purchases on impulse. Here H0 is Accepted.

Table- V: Analysis of Income and Consumers' Opinion

H03: There is no association between income and consumers' opinion Regression Analysis

\begin{tabular}{|l|c|c|c|r|r|l|}
\hline \multirow{2}{*}{ Model } & \multicolumn{2}{|c|}{$\begin{array}{l}\text { Unstandardized } \\
\text { Coefficients }\end{array}$} & $\begin{array}{l}\text { Standardized } \\
\text { Coefficients }\end{array}$ & \multirow{2}{*}{$\mathrm{T}$} & Sig. & \multirow{2}{*}{$\mathrm{H}_{0}$} \\
\cline { 2 - 5 } & B & Std.Error & \multicolumn{1}{|c|}{ Beta } & & & \\
\hline (Constant) & 6.531 & 1.067 & & 6.121 & $\begin{array}{r}.00 \\
0\end{array}$ & Reject \\
\hline $\begin{array}{l}\text { I often buy things } \\
\text { impulsively }\end{array}$ & -.403 & .139 & -.337 & $\begin{array}{r}-2.90 \\
3\end{array}$ & $\begin{array}{r}.00 \\
5\end{array}$ & Reject \\
\hline $\begin{array}{l}\text { I often buy things } \\
\text { exclusive of } \\
\text { thinking }\end{array}$ & .040 & .149 & .042 & .268 & $\begin{array}{r}.79 \\
0\end{array}$ & Accept \\
\hline $\begin{array}{l}\text { Buy now, and feel } \\
\text { later describes me }\end{array}$ & -.557 & .152 & -.482 & $\begin{array}{r}-3.65 \\
7\end{array}$ & $\begin{array}{r}.00 \\
0\end{array}$ & Reject \\
\hline
\end{tabular}

\begin{tabular}{|c|c|c|c|c|c|c|}
\hline $\begin{array}{l}\text { I bought more than } \\
\text { I had considered } \\
\text { buying }\end{array}$ & -.083 & .165 & -.058 & -.500 & $\begin{array}{r}.61 \\
9\end{array}$ & Accept \\
\hline $\begin{array}{l}\text { I felt exciting } \\
\text { shopping when in } \\
\text { time of online sites }\end{array}$ & .057 & .206 & .041 & .278 & $\begin{array}{r}.78 \\
2\end{array}$ & Accept \\
\hline $\begin{array}{l}\text { I buy a product or } \\
\text { services to lift my } \\
\text { mood that moment }\end{array}$ & -.543 & .202 & -.429 & $\begin{array}{r}-2.69 \\
2\end{array}$ & $\begin{array}{r}.00 \\
9\end{array}$ & Reject \\
\hline $\begin{array}{l}\text { I buy things } \\
\text { according to think } \\
\text { at a moment }\end{array}$ & .223 & .175 & .198 & 1.274 & $\begin{array}{r}.20 \\
7\end{array}$ & Accept \\
\hline $\begin{array}{l}\text { Spontaneous } \\
\text { buying make me } \\
\text { happy to shop } \\
\text { impulsively }\end{array}$ & .586 & .218 & .493 & 2.691 & $\begin{array}{r}.00 \\
9\end{array}$ & Reject \\
\hline $\begin{array}{l}\text { I carefully plan } \\
\text { most of my } \\
\text { shopping moment }\end{array}$ & -.214 & .149 & -.158 & $\begin{array}{r}-1.43 \\
4\end{array}$ & $\begin{array}{r}.15 \\
6\end{array}$ & Accept \\
\hline $\begin{array}{l}\text { For me, shopping } \\
\text { is an adventure }\end{array}$ & .564 & .190 & .442 & 2.962 & $\begin{array}{r}.00 \\
4\end{array}$ & Reject \\
\hline $\begin{array}{l}\text { I buy product or } \\
\text { services if I can get } \\
\text { free products }\end{array}$ & -.154 & .156 & -.146 & -.990 & $\begin{array}{r}.32 \\
5\end{array}$ & Accept \\
\hline $\begin{array}{l}\text { Free services can } \\
\text { be the reason for } \\
\text { me to buy on } \\
\text { impulse }\end{array}$ & -.009 & .132 & -.008 & -.065 & $\begin{array}{r}.94 \\
9\end{array}$ & Accept \\
\hline $\begin{array}{l}\text { I buy the product } \\
\text { online with } \\
\text { various offers and } \\
\text { discounts }\end{array}$ & .563 & .207 & .385 & 2.720 & $\begin{array}{r}.00 \\
8\end{array}$ & Reject \\
\hline $\begin{array}{l}\text { If I see an } \\
\text { economical price, } \\
\text { I tend to buy } \\
\text { impulse }\end{array}$ & -.745 & .302 & -.532 & $\begin{array}{r}-2.46 \\
7\end{array}$ & $\begin{array}{r}.01 \\
6\end{array}$ & Reject \\
\hline $\begin{array}{l}\text { I usually make } \\
\text { purchases on } \\
\text { impulse. }\end{array}$ & -.525 & .284 & -.401 & $\begin{array}{r}-1.85 \\
2\end{array}$ & $\begin{array}{r}.06 \\
8\end{array}$ & Accept \\
\hline
\end{tabular}

Table $\mathrm{V}$ examines the Association between income and consumers' opinion. There is no significant association between income and consumers' opinion about I often buy things exclusive of thinking, I bought more than I had considered buying, I felt exciting shopping when in time of online sites, I buy things according to think at a moment, I carefully plan most of my shopping moment, I buy product or services if I can get free products, Free services can be reason for me to buy on impulse, I usually make purchases on impulse. Here H1 is Rejected.

There is significant relationship between income and consumers' opinion about often buy things impulsively, Buy now, and feel later describes me, I buy a product or services to lift my mood that moment, Spontaneous buying make me happy to shop impulsively, For me, shopping is an adventure, I buy product in online with various offers and discounts, If I see an economical price, I have a tendency to buy impulse. Because the null hypothesis is rejected 


\section{VII.FINDINGS}

In gender orientation there is a critical connection between consumers' supposition about unconstrained buying fulfil me to shop impulsively, I purchase item or administrations if I can get free items, I, for the most part, make buys on impulse. For in the age shrewd there is no critical connection between consumers' conclusion about I regularly purchase things suddenly, Purchase now, and think later portrays me, I cautiously plan the more significant part of my shopping minute, and I purchase item or administrations. In the salary examination of difference of relapse investigation there is a noteworthy connection between consumers' conclusion about frequently purchase things precipitously, Purchase now, and think later portrays me, I purchase an item or administrations to lift my temperament that minute, Unconstrained buying fulfil me to shop impulsively, For me, shopping is an experience.

\section{CONCLUSION:}

This study has made an endeavour to comprehend the points of interest in online buying conduct. In light of the extensive writing audit, the different part of impulse buying in the setting of online stores is incorporated. It is discovered that constructive outcome of financial variables of age, sexual orientation, pay and the consumer supposition about online impulsive buying conduct of Unconstrained buying fulfills me to shop impulsively, For me, shopping is an experience, I purchase item in online with different offers and limits, On the off chance that I see a limited value, I will in general purchase impulse. Along these lines, we can support online retailers and produces to more readily comprehend the best approach to animate the impulse buying of consumers. Correspondingly, both the retailers and fabricates can all the more likely fulfil individuals' needs, in this way improving the intensity of shopping destinations and organizations.

\section{REFERENCES:}

1. Azim, A. Effect of dynamic environment, customers' tendency towards promotion and new experiences on impulse buying. Management and Administrative Sciences Review, Vol. 2(3), 281-292,(2013).

2. Cox, K, "The Responsiveness of Food Sales to Shelf Space Changes in Supermarkets", Journal of Marketing Research, Vol. 1, May, pp. 63-67(1964).

3. Dittemar, H., Beattie, J., and Friese, S, “ObjectsDecision Considerations and self-image in men's and Women's impulse purchases", Actapsychologia, 93, pp.187-206(1996).

4. John D. "Self-image- is it in the bay? A qualitative Comparison between 'ordinary' and 'excessive' consumers", Journal of Economic Psychology, 21, pp. 109-142, (2000)

5. Falahat, M., Osman, M. \&Migin, M.W. Born Global Firms in Developing Economies: The Case of Malaysia. Australian Journal of Basic and Applied Sciences, 7(4), 586-594,(2013).

6. Kang Lo S., Chou Y., Teng Ch. Source effect of advertised reference price influences on transaction value in online shopping environments. Electronic Commerce Res,Vol. 13, p. 411-421, 2013.

7. Kathiravan, C., \& Deepak, R. K.. Public Cognizance on Cause Assortment in Cause Affiliated Campaigns. International Journal of Marketing, Financial Services \& Management Research, 2(9), (2013).

8. Muruganantham, G., \&Bhakat, R. S. A review of impulse buying behavior. International Journal of Marketing Studies, Vol. 5(3), 150-160, (2013).

9. Newman, S. and Lloyd Jones, T., Airport and travel terminal retailing Strategies, Trends and market dynamics. Ravenfox publishing, London,(1999).

10. Tol, B. v. Electronic commerce and technology. Ottawa: Statistics Canada, (2003)

11. Tol, B. v. Electronic commerce and technology. Retrieved August 24, 2004,

12. Zhang, X., Prybutok, V. R., \&Strutton, D..Modeling influences on impulse purchasing behaviors during online marketing transactions. Journal of Marketing Theory and Practice, 1(15), 79-89, (2007). doi:10.2753/MTP1069-6679150106

\section{AUTHORS PROFILE}

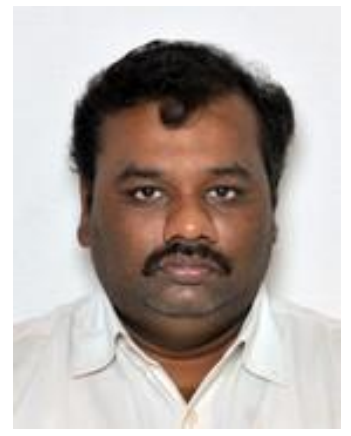

Dr. C. Kathiravan, M.B.A., Ph.D, is currently working as a Associate Professor, Department of Business Administration, Annamalai University, Tamilnadu, India. He has more than 15 years of teaching experience at PG level and more than 14 years of Experience in Research. He has published more than 80 articles in National and International Journals and more than 3 books in his credit and also attended many national and international conferences, seminars and workshops. He is a member of many professional bodies and also a member of reviewer panels of national and International Journals. His field of specialization is Marketing, E-commerce \& Strategic Management and the main area of research interest is Competitive Advantage, Digital Marketing, Social Media Marketing etc.

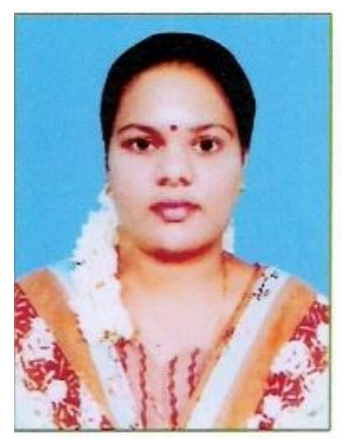

P.Mahalakshmi.M.B.A.,is a Research scholar, department of Business Administration,

AnnamalaiUnivesityTamilnadu,India,

Published a paper titled, Exploring the effects of media formats emotions on Impulse buying tendency in the Digital era ,in the book volume I ,Commerce and Management era.Number 141-148 ISBN :978-93-87756-71-7. Participated international conference on "Advanced Marketing (ICAM)" organized by Kalasalingam academy of Research and Education \&University of Kelaniya, Srilanka.In this conference presented, paper titled "Impact Disruption on Impulse buying in the Retail Market" and also attended many National and International conferences, Seminars, FDP Workshops. Her field of specialization is Marketing, Digital Marketing, E-Commerce etc. 
Online Impulse Buying Behavior of Consumer Triggered by Digital Marketing

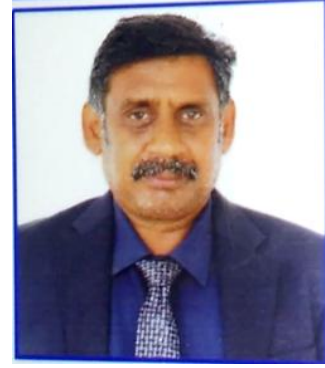

V.Palanisamy MBA M,Phil, is currently working as an Assistant Professor, Department of Management Studies, St. Joseph University, Nagaland, India. He has more than 6 years of teaching experience and 15 years of Experience in Industry. He has published more than 10 articles and books by the National and International publishers and also for his credit he also attended many national and international conferences, seminars and workshops. He is the active member of many professional bodies, reviewer and editorial panels of many national and International Journals. His field of specialization is Marketing, HR \& Strategic Management and the main area of research interest is Digital Marketing, Social Media Marketing etc. 